\title{
COMPARISON OF HSR LINES IN TURKEY AND THE WORLD AND THEIR SPATIAL IMPACT: A CASE STUDY OF THE ANKARA-KONYA HSR LINE
}

\author{
AHMET BAŞ \& MEHMET ALI YÜZER \\ Faculty of Architecture, Urban and Regional Planning Department, \\ Istanbul Technical University, Turkey
}

\begin{abstract}
High-speed train services have been implemented in many different countries of the world since it was first introduced in Japan in 1964. High Speed Railways (HSRs) are it extremely attractive for countries due to rapid travel with high speeds among long-distance settlements. HSR investments have increased in recent years in Turkey after the determination of HSR developments as a national policy by the Turkish Government. 888 km HSR lines were constructed between Ankara-Eskişehir, Ankara-Konya and Ankara-Istanbul from 2002 to 2014.The aim of this study is to find out how HSR lines effect the distribution of population, labour capacity, time efficiency as well as urban sprawl in the Ankara-Konya region. To explore the impact of HSR lines, a new model is developed to satisfy the former goals, model computes the data not only from the statistical part also estimation of the future activity distributions. Basically, there are two main components in the developed model. First is to calculate the accessibility of HSR in the region. The second to figure out HSR's spatial impact in the city. A utility function has been composed and interviews have been conducted with HSR passengers. Besides, public transport system also examined in terms of accessibility in the second part of the model. In addition, the study reveals the socio-economic and spatial effects of HSR lines to Ankara-Konya region, which is the first implemented line as a new one in Turkey.
\end{abstract}

Keywords: high speed train, accessibility, spatial impact.

\section{INTRODUCTION}

So far HSRs are the basic dominant transportation modes for the last decades not only for developed countries also for developing countries in terms of making connections between regions and cities. In addition, by the HSR systems, railways can compete with other transportation modes and make corridors to enhanced regional development. As seen in Table 1 could be realized, railway future is as brightly as it never happens before since $19^{\text {th }}$ century. Today, HSR systems are completed, under construction or planned in 39 countries and whole length of railway lines are 89,347 km (Table 1).

Since the inception of high-speed train service in Japan for the first time in 1964, it has been the subject of discussion of many scientific studies and reports. These studies are commonly arranged from the point of economic view; infrastructure and costs [1]-[3] engineering services, deploy, performance and fertility [4]-[7]. Besides, there are also some studies which are about the social, cultural and spatial impact of high speed railways (HSR) such as [8]-[15]. Most of these studies argue that HSR systems have a significant transform effects on the time distance, spatial development and social convergence. On the contrary, there are also some studies which show that HSR systems have some disadvantages from the point of spatial equity [16] or some small cities suffer by not being in the HSRs network [17].

HSR issues were discussed in Turkey simultaneously with the other countries. For instance, HSR systems were discussed in the Second National Plan meetings in 1968 [20]. However, the first HSR line construction was started in 2005 and run in 2009 between Ankara and Eskişehir in Turkey. There was a conventional line in the same route until the HSR service run between the cities. Moreover, another new line also constructed between Ankara-Konya and there wasn't a railway service since HSR line constructed in this route. 
Thus Ankara-Konya HSR service is the first, modern and terminologically the first HSR line in Turkey and it was started to run in 2010.

In substance, this study aims to show how HSRs effect the selection of transportation modes, enhance accessibility, distribution of population in a city and spatial choice. To show the impact of HSR lines, a model has been used to satisfy the former goals, model computes the data not only from the statistical part also estimation of the future activity distributions. Basically, there are two main components in the model. One is to calculate the accessibility of HSR in the city and region. The second one is figured out the spatial impact in city. A utility function has been composed and interview made with the passengers of HSR.

Table 1: HSRs; run, under construction and planned lines according to countries [18], [19].

\begin{tabular}{|c|c|c|c|c|}
\hline Country & Run & $\begin{array}{c}\text { Under } \\
\text { construction }\end{array}$ & Planned & Total \\
\hline Australia & 0 & 0 & 1749 & 1749 \\
\hline Austria & 48 & 218 & 0 & 266 \\
\hline Bahrain-Qatar & 0 & 0 & 180 & 180 \\
\hline Estonia, Lithuanian, Latvia & 0 & 0 & 740 & 740 \\
\hline Belgium & 209 & 0 & 0 & 209 \\
\hline Brazil & 0 & 0 & 511 & 511 \\
\hline Canada & 0 & 0 & 1590 & 1590 \\
\hline China & 23914 & 10730 & 1525 & 36169 \\
\hline Czech Republic & 0 & 0 & 890 & 890 \\
\hline Denmark & 0 & 56 & 0 & 56 \\
\hline Egypt & 0 & 0 & 1210 & 1210 \\
\hline England (UK) & 113 & 0 & 543 & 656 \\
\hline France & 2142 & 634 & 1786 & 4562 \\
\hline Germany & 1475 & 368 & 324 & 2167 \\
\hline India & 0 & 0 & 4630 & 4630 \\
\hline Indonesia & 0 & 0 & 730 & 730 \\
\hline Iran & 0 & 425 & 870 & 1295 \\
\hline Italy & 981 & 67 & 221 & 1269 \\
\hline Japan & 3041 & 402 & 179 & 3622 \\
\hline Kazakhstan & 0 & 0 & 1011 & 1011 \\
\hline Malaysia-Singapore & 0 & 0 & 350 & 350 \\
\hline Mexico & 0 & 0 & 210 & 210 \\
\hline Morocco & 0 & 183 & 480 & 663 \\
\hline Netherland & 120 & 0 & 0 & 120 \\
\hline Norway & 0 & 0 & 333 & 333 \\
\hline Poland & 224 & 0 & 1127 & 1351 \\
\hline Portugal & 0 & 0 & 596 & 596 \\
\hline Russia & 0 & 0 & 2978 & 2978 \\
\hline Saudi Arabia & 0 & 453 & 0 & 453 \\
\hline South Africa & 0 & 0 & 2390 & 2390 \\
\hline South Korea & 657 & 120 & 49 & 826 \\
\hline Spain & 2871 & 1262 & 1327 & 5460 \\
\hline Sweden & 0 & 0 & 740 & 740 \\
\hline Switzerland & 144 & 15 & 0 & 159 \\
\hline Taiwan-China & 354 & 0 & 0 & 354 \\
\hline Thailand & 0 & 0 & 2877 & 2877 \\
\hline Turkey & 888 & 599 & 1334 & 2785 \\
\hline USA & 362 & 483 & 1029 & 1874 \\
\hline Vietnam & 0 & 0 & 1600 & 1600 \\
\hline Total & 37543 & 16079 & 36109 & 89731 \\
\hline
\end{tabular}




\section{COMPARISON OF HSRS IMPLICATIONS IN THE WORLD AND IN TURKEY}

\subsection{Current circumstances in HSRs in the world and in Turkey}

There isn't a unique explanation of high speed train (HST) even it defines mostly exceed $250 \mathrm{~km} / \mathrm{h}$ speed [21]. In terms of this explanation Shinkansen is the first HST services which was firstly managed in 1964 although the speed was achieved $200 \mathrm{~km} / \mathrm{h}$ in 1903 and in France, $331 \mathrm{~km} / \mathrm{h}$ in 1955. However, these speeds are not the operating speeds [8], [22].

Narrow or wider gauge couldn't allow to make high speed such as $250 \mathrm{~km} / \mathrm{h}$ or more, so modern HSRs lines need to run into standard gauge. In some countries, new HSR lines are constructed apart from the conventional lines as Japan, Spain, Turkey. Therefore, HSRs investments are so much expensive because of construction costs and high land price. On the other hand, as Givoni cited French TGV systems also reduce the construction cost by using the conventional lines in city centers [23]. This shows that HSRs and conventional lines also could be run together. Moreover, German ICE managed a mixed-use line, namely it is used for both passenger and freight transport [8]. By this way, basic expensive construction cost argument of HSR eliminated.

China's HSRs systems need to be mentioned in apart. As of 2007, there is no HSR line in China. However, just in last decades more than 23,000 km HSR lines constructed and half of this number is under construction. After all constructions accomplished, total length of China's HSR lines will be $36,169 \mathrm{~km}$ and this is almost half of whole length of HSR lines in the world. China's main aim is to connect all provincial cities with other big cities and make a HSR network connection. This connection enhances the accessibility of cities conspicuously [24]. Additionally, HSRs investments are found to have a strong and positive effect on national and economic growth and social welfare [7].

The construction of Ankara-Eskişehir line, which started in 2003, was completed and run in 2009. Before the construction, there was another conventional line in the same route. Basic improvement for HSR line is to reduce time between cities. By HSR line it reduces 1 hour 25 minutes from 2.5 hours. However, even the line updated use a tilting mechanism as suitable for high speed train, herewith the line didn't construct newly. All curves, gauge and other technical notions is suitable for conventional line. So terminologically it isn't true to call this line as HSR line.

Second HSR line was constructed between Ankara-Konya. This line has some differences compare to Ankara-Eskişehir line. First of all, there wasn't a railway between the cities since HSR line constructed. Thus, whole route is designed for high speed trains. The line construction was ended in 2010 and run in 2011. Total line is $306 \mathrm{~km}$ and it takes only 1 hour 15 minutes from Ankara to Konya. It is extremely important for Konya due to time reduce. Before HSR line, it takes nearly 3.5 hours by bus and 2 hours by car.

According as the TCDD Annual Report 2015 total length of HSR lines is $888 \mathrm{~km}$. Moreover, $405 \mathrm{~km}$ of Ankara-Sivas and $194 \mathrm{~km}$ of Ankara-Afyonkarahisar HSR lines are under construction. Ankara-Eskişehir, Ankara-Konya, Ankara-İstanbul and Konya-İstanbul lines are in operation in order of 2010, 2011 and 2014. Total passenger number is more than 23 million and total income from passengers is nearly 500 million TL (150 million \$).

\subsection{New horizons for HSRs}

HSR systems make a big deal with shaping of cities, discontinuous spaces and time reduces. Besides, it is creating strong polarizations around the station and in the city. In most of the 
cases, HSRs are good opportunities for cities to change the relationship between the city and region as well as infrastructure [25]. Today, HSR systems more than a transportation mode. It played an active role by cities and regions through government intervention [22].

While HSR lines are being constructed, technological and mechanical systems also have been improved. In terms of speed, the MAGLEV (Magnetic Levitation) technology is an upgrade of high speed train. The technology based on electromagnetic forces to cause the vehicle to hover above the track and move forward at theoretically unlimited speeds [8]. As Takagi cited from EU Research "Although there are, no doubt, some who dream of trains achieving even higher speeds, this is not a realistic prospect. Noise, vibration, the cost of maintaining the track and rolling stock, and energy consumption (up by $50 \%$ for an increase in train speed from $300 \mathrm{~km} / \mathrm{h}$ to $360 \mathrm{~km} / \mathrm{h}$ ) would all increase excessively for just a marginal time-saving" [26]. The manner still carries on and it needs some new prospects to balance the cost and benefit.

After a successful privatization and division of Japanese National Railways (JNR) in 1987, many EU countries privatized their railways in the 1990s [26]. Same process is going to be continue for Turkish State Railways (TCDD). TCDD's administration is divided into 2 groups: one is responsible for infrastructure and other is going to manage the travels and

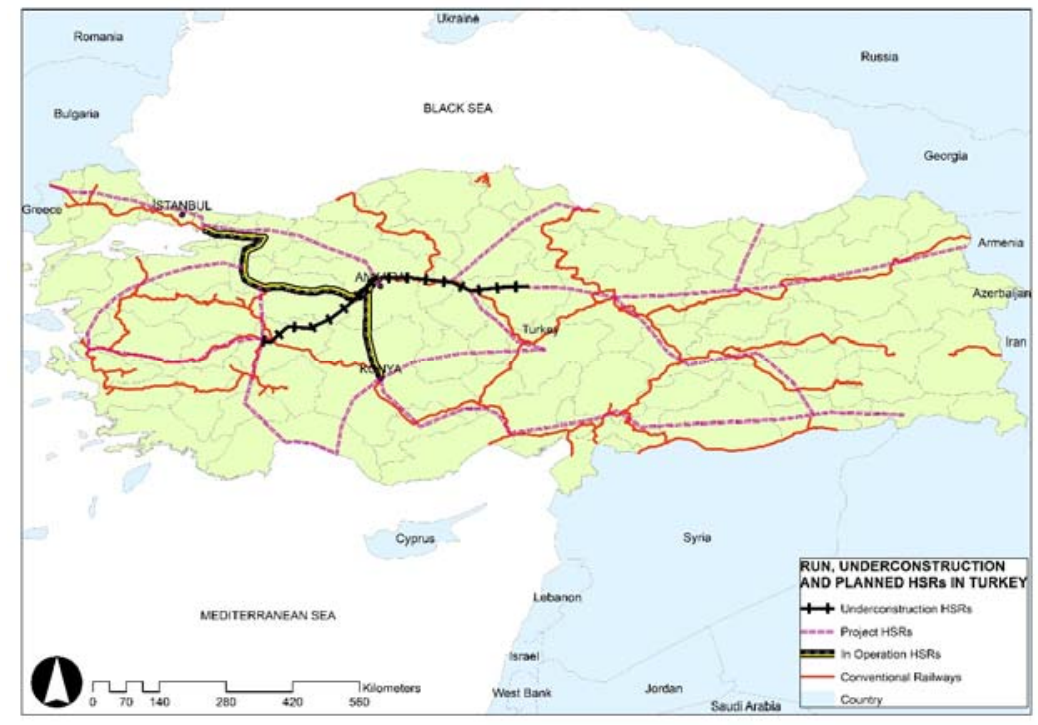

Figure 1: Railways map in Turkey. (Source: Map is drawn by authors by using TCDD (Turkish State Railways) data and annual reports.)

Table 2: Total passenger numbers annually carrying by Turkish HSRs [18].

\begin{tabular}{|l|r|r|r|r|r|r|}
\hline HSR Lines & \multicolumn{1}{|c|}{2010} & 2011 & \multicolumn{1}{c|}{2012} & \multicolumn{1}{c|}{2013} & \multicolumn{1}{c|}{2014} & \multicolumn{1}{c|}{2015} \\
\hline Konya-Ankara & 0 & 406,636 & $1,371,369$ & $1,744,605$ & $1,890,320$ & $1,437,291$ \\
\hline Konya-İstanbul & 0 & 0 & 0 & 0 & 30,776 & 527,604 \\
\hline Ankara-İstanbul & 0 & 0 & 0 & 0 & 992,098 & $1,564,249$ \\
\hline Ankara-Eskişehir & $1,889,666$ & $2,149,879$ & $1,978,155$ & $2,264,394$ & $1,924,431$ & $1,019,845$ \\
\hline HSR Total Passenger & $1,889,666$ & $2,556,515$ & $3,349,524$ & $4,207,324$ & $5,085,697$ & $4,548,989$ \\
\hline
\end{tabular}

Note: 2015 data is as of $19^{\text {th }}$ October of 2017. 
other stuffs. It is expected that in a few years, second part of TCDD, which is called TCDD Taşımacılık A.Ş. today, will be privatized same as Japan and other EU countries. Main important thing in HSR investments is expensive construction costs. Except China, it looks hard to construct a HSR line without state subsidies. In a near future, other developing countries may try to use the same method as Japan or EU countries. Likewise, there is a big improvement on the other transportation modes. Especially in air transportation, flying cars could be change all our thoughts [27]. Perhaps, it seems to use it so far in a short time but as we know that, railway investments once constructed, it is used more than hundred years. During this process, all indicators must be evaluated in terms of using effective public sources.

\section{CASE STUDY}

\subsection{General information about case area}

The first settlement in Konya was settled in Catalhöyük in south-east part of Konya 8000 years ago. Thus, Konya has a long historical heritage from the point of archaeological evidence. Therefore, the city was the capital of Anatolian Seljuk Empire. As a result of this, there are so many historical place and monuments in the city. So, it makes the city a tourism hub in the center of Anatolia. Nearly 1.3 million tourists visit the city annually. Today, more than 2 million people live in Konya. Moreover, there are 3 universities in the city and 125,611 students educated in the city (Table 2). Besides the city has 6 industrial zones and more than 100 thousand people work in these zones. On the other hand, the city far from the capital of Turkey-Ankara just $258 \mathrm{~km}$ as well as Istanbul is $662 \mathrm{~km}$ away from Konya. So far the city Konya located in the crossroad center of Anatolia and it is easy to reach the city from north to south and west to east part of Anatolia. There is an international airport close to city in which there are 9-10 flights in a day according as the different airline companies.

Total settlement area, including commercial, educational, health and other daily facilities, is about 22,457 ha according as land use data. Industrial zone areas are covered 6,532 ha of city (Fig. 1). To sum up total area is 28,989 ha and modelling area is nearly 830 ha (3\% of whole study area).

\subsection{Survey analysis}

\subsubsection{Accessibility analysis}

HSRs are very efficient in terms of time distance between $250-750 \mathrm{~km}$. Outside of these distance bus, conventional trains, car and air transportations are more efficient compare to railways [8]. The distance of cities in which the accessibility measures are calculated for them are given in the Table 2.

Table 3: General statistical data for Konya [28]-[31].

\begin{tabular}{|l|r|r|r|r|}
\hline Years & $\begin{array}{c}\text { Population } \\
\text { (Person) }\end{array}$ & Employee (Person) & $\begin{array}{c}\text { Student } \\
\text { (Person) }\end{array}$ & $\begin{array}{c}\text { Tourist } \\
\text { (Person) }\end{array}$ \\
\hline 2010 & $2,013,845$ & 389,004 & 76,166 & $1,803,375$ \\
\hline 2011 & $2,038,555$ & 419,620 & 84,324 & $1,926,015$ \\
\hline 2012 & $2,052,281$ & 446,286 & 92,616 & $1,811,335$ \\
\hline 2013 & $2,079,225$ & 455,335 & 104,153 & $2,313,293$ \\
\hline 2014 & $2,108,808$ & 475,984 & 111,800 & $2,298,027$ \\
\hline 2015 & $2,130,544$ & 499,531 & 125,611 & $2,254,689$ \\
\hline
\end{tabular}




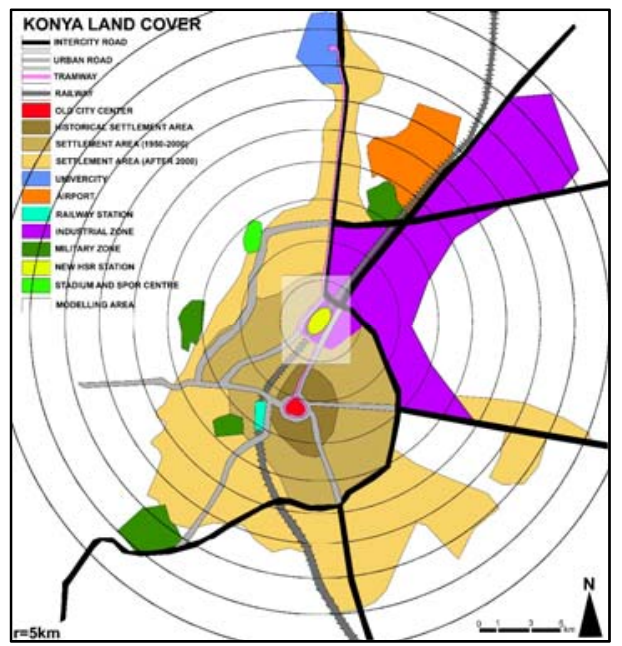

Figure 2: Land cover of Konya. (Source: Map is drawn by author by using Konya Metropolitan Municipality data and satellite photos.)

Accessibility analysis is one of the input indicator in order to calculate the utility differences of transportation modes or destinations [32]. Therefore, it has been used in different aspect of travel demand forecasting, location choice and appraisal of land-use changes [33]. Beside as Chandra and Vadali also studied an accessibility analysis of USA Appalachia region; accessibility effects not only from the point of distance also economic activities in the region [34].

In most of the accessibility studies there is a basic equation to calculate the time differences between the cities. To carry out this study, basically there have been calculated three indicators which are duration, distance and population as shown in the eqn 1 :

$$
\mathrm{A}_{\mathrm{i}}=\frac{\sum_{\mathrm{j}=1}^{\mathrm{n}}\left(\mathrm{T}_{\mathrm{ij}} \cdot \ln \mathrm{M}_{\mathrm{j}}\right)}{\sum_{\mathrm{j}=1}^{\mathrm{n}}\left(\ln _{\mathrm{j}}\right)},
$$

where $A_{i}$ refers the accessibility of city $i, T_{i j}$ refers to the travel time and $M_{j}$ refers to the population of city. To eliminate the effects of the population difference and determine the travel time impact, a logarithmic exchange has been made to the number of population.

Accessibility analysis also gives the distribution of population in a city according to their location choice in terms of train station. By this way, not only regional accessibility, also inner-city accessibility is determined to find out the distribution of passengers in the city which is mentioned in spatial analysis part.

For automobile trips speed is $120 \mathrm{~km} / \mathrm{h}$ in autobahn and $110 \mathrm{~km} / \mathrm{h}$ for other intercity roads. HSR and airline trips time is calculated from the departure and arrival time from train station and airport. Spending time in the city and other transportation modes don't calculate in the duration. Intercity buses give a break for each 3 hours. Time is calculated according to this data. 
Table 4: Distance and duration (minutes) according to the transportation modes between the cities of Konya, Ankara and İstanbul. (Source: Distance derived from [35]. Durations are calculated by authors according as legal speed limit.)

\begin{tabular}{|c|c|c|c|c|c|c|c|c|c|c|c|c|c|c|c|}
\hline Modes & \multicolumn{3}{|c|}{ Automobile } & \multicolumn{3}{|c|}{ HSR } & \multicolumn{3}{|c|}{ Bus } & \multicolumn{3}{|c|}{ Airline } & \multicolumn{3}{|c|}{ Distance $(\mathrm{km})$} \\
\hline City & $\underset{\overparen{D}}{\stackrel{\pi}{0}}$ & $\begin{array}{l}\text { 㺃 } \\
\text { 思 }\end{array}$ & $\begin{array}{l}\bar{\Xi} \\
\tilde{\Xi} \\
\text { 芯 }\end{array}$ & 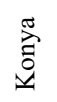 & $\frac{\pi}{\frac{\pi}{\tilde{J}}}$ & 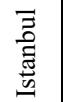 & $\begin{array}{l}\stackrel{\tilde{D}}{\overrightarrow{0}} \\
\stackrel{0}{\Delta}\end{array}$ & $\begin{array}{l}\text { 㺃 } \\
\text { 龸 }\end{array}$ & $\begin{array}{l}\bar{\Xi} \\
\bar{E} \\
\underline{E}\end{array}$ & $\begin{array}{l}\stackrel{\widetilde{\Delta}}{0} \\
\stackrel{0}{\Delta}\end{array}$ & $\begin{array}{l}\text { 莺 } \\
\text { 娄 }\end{array}$ & $\begin{array}{l}\bar{\Xi} \\
\text { 芯 } \\
\text { 苞 }\end{array}$ & 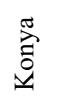 & 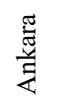 & $\begin{array}{l}\bar{\Xi} \\
\bar{\Xi} \\
\text { 芯 }\end{array}$ \\
\hline Konya & 0 & 150 & 435 & 0 & 103 & 278 & 0 & 200 & 545 & 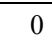 & 0 & 70 & 0 & 258 & 662 \\
\hline Ankara & 150 & 0 & 200 & 103 & 0 & 255 & 200 & 0 & 420 & 0 & 0 & 60 & 258 & 0 & 453 \\
\hline Istanbul & 435 & 200 & 0 & 278 & 255 & 0 & 545 & 420 & 0 & 70 & 60 & 0 & 662 & 453 & 0 \\
\hline
\end{tabular}

Table 5: Accessibility index. (Source: Index are calculated by authors.)

\begin{tabular}{|c|c|c|c|c|c|c|c|c|c|c|c|c|}
\hline & \multicolumn{3}{|c|}{$\begin{array}{c}\mathrm{Ai} \\
\text { (Automobile) }\end{array}$} & \multicolumn{3}{|c|}{$\begin{array}{c}\mathrm{Ai} \\
\text { (High Speed Train) }\end{array}$} & \multicolumn{3}{|c|}{$\begin{array}{c}\mathrm{Ai} \\
\text { (Bus) }\end{array}$} & \multicolumn{3}{|c|}{$\begin{array}{c}\mathrm{Ai} \\
\text { (Airline) }\end{array}$} \\
\hline & 节 & 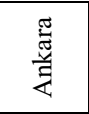 & 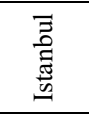 & 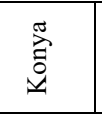 & 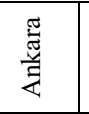 & 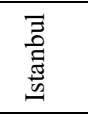 & 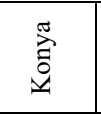 & 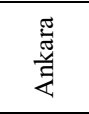 & 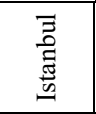 & 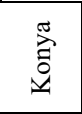 & 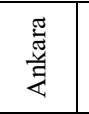 & 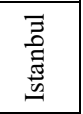 \\
\hline Kony & 0 & 72.77 & 211.03 & 0 & \begin{tabular}{|l|}
53.03 \\
\end{tabular} & 147.59 & 0 & 102.97 & 289.35 & 0 & 0 & 37.16 \\
\hline Ankara & 77.23 & 0 & 96.79 & 499.97 & 0 & 131.6 & \begin{tabular}{|c|}
93.82 \\
\end{tabular} & 0 & 216.75 & 0 & 0 & 30.96 \\
\hline Istanbul & 224.49 & 103.21 & 0 & 130.41 & \begin{tabular}{|l|}
123.4 \\
\end{tabular} & 0 & 255.65 & 203.25 & 0 & 37.16 & \begin{tabular}{|l|}
30.96 \\
\end{tabular} & \\
\hline
\end{tabular}

Table 6: Transformation of passenger choice between transportation modes [36].

\begin{tabular}{|l|r|r|r|r|}
\hline \multirow{2}{*}{ Transportation mode } & \multicolumn{2}{|c|}{ Ankara-Konya (\%) } & \multicolumn{2}{c|}{ Ankara-Eskişehir (\%) } \\
\cline { 2 - 5 } & Before HSR & After HSR & Before HSR & \multicolumn{1}{c|}{ After HSR } \\
\hline Bus & 70 & 35 & 55 & 10 \\
\hline Automobile & 29 & 11 & 37 & 18 \\
\hline High-speed train & - & 54 & 8 & 72 \\
\hline
\end{tabular}

When the accessibility index is examined according to the transportation modes, it is clearly seen that high-speed train improved the accessibility between the cities. This makes a big change on the transportation mode choice. As seen in the Table 4, most of the bus and automobile passengers give up their mode and select high-speed train. On the contrary, bus transportation is the most suffer modes between Ankara-Konya and Ankara-Eskişehir. As it is seen in Table 6, opening a new HSR line can affect the demand on the route as well as changing the connections, pattern of network usage and performance [5]. Most of the bus companies, in which work on these lines, decrease their trips and dismiss their employees.

\subsubsection{Spatial impact analysis}

Over the last 30 years, the spatial modelling systems and programs have been increased so much. Cellular automata was studied in the early 1950s by Wolfram [37] and he called cellular automata; simple to allow detailed mathematical analysis, but complex to exhibit a wide variety of complicated phenomena [38]. Cellular automata are used to analysis the changing of space according as defined cells. At this point, we can simply clarify it; space divided into the cells, these cells define one state of a function for a certain time and all cells are in an interaction between others. Thus, there is transition that drives changes of state in each cell as some function of what exists or is happening in the cell's neighborhood [39]. This is a useful way to make a simulation for future. However, the model doesn't compute 
the social behaviors or policies. So, the modelling gives an indicator to forecast the future circumstances.

In the case study, spatial impact analysis has basically two steps. The first step is clarifying the accessibility index of each cells (Fig. 2) according as public transport and private car. Secondly a utility function (eqn (2)) is examined in each cell to find out the utility. Cells are defined into eight categories depend on their functional manners. These categories are: continuous settlement area, discontinuous settlement area, development area, commercial area, industrial area (OIZ, SIZ), green area, recreational area and empty area [10]. Continuous area clarifies the housing place in which the cell is fully settled. Discontinuous area is half of the cell is settled and the other is empty. Development area defines the place where new settlements are going to be constructed. There are two types of industrial zones. One is organized industrial zone (OIZ) and the other is small industrial zone (SIZ) area. Green area defines the park and other open space areas. Recreational area is consisting of the place in which people spend their leisure time such as aqua parks, enjoy facility areas etc.

$$
\mathrm{U}_{\mathrm{t}}=\mathrm{c}_{\mathrm{i}}+\mathrm{W}_{\mathrm{g}}+\mathrm{W}_{\mathrm{r}}+\mathrm{W}_{\mathrm{a}}+\mathrm{W}_{\mathrm{e}}+\mathrm{W}_{\mathrm{t}}+\mathrm{W}_{\mathrm{s}},
$$

where $U_{t}$ defines the utility of any transportation mode in a cell. $c_{i}$ shows the tendency of an $i$ person to a transportation mode. $W_{g}$ shows the personal income. $W r$ shows the trip reason, $W a$ is the age of person, $W_{e}$ ownership of a driving license, $W_{t}$ shows the spending time for an i person and $W_{s}$ shows the impact of security on an i person [40].

$$
T^{t t}(i, j)=T_{O}\left(i, E_{i}\right)+T_{I V}\left(E_{i}, E_{j}\right)+T_{D}\left(E_{j}, j\right)+\tau p .
$$

According to the eqn (3) public transport duration calculated. $\mathrm{T}_{\mathrm{O}}$ shows the duration of walking time in which the distance from i point to nearest bus or railway station $\left(\mathrm{E}_{\mathrm{i}}\right)$. $\mathrm{T}_{\mathrm{IV}}$ refers to trip time that is spend in the car from station $\left(E_{i}\right)$ to $j$ arrival station $\left(E_{j}\right) . T_{D}$ shows the duration of walking time in which the distance from station $\left(\mathrm{E}_{\mathrm{j}}\right)$ to $\mathrm{j}$ arrival point. $\tau_{\mathrm{p}}$ is random variable and shows the unexpected delays or cancels [10].

$$
\mathrm{T}^{\mathrm{a}}(\mathrm{i}, \mathrm{j})=\mathrm{T}_{\mathrm{O}}\left(\mathrm{i}, \mathrm{N}_{\mathrm{i}}\right)+\mathrm{T}_{\mathrm{a}}\left(\mathrm{N}_{\mathrm{i}}, \mathrm{N}_{\mathrm{j}}\right)+\mathrm{T}_{\mathrm{D}}\left(\mathrm{N}_{\mathrm{j} j} \mathrm{j}\right) \text {. }
$$

According to the eqn 4 private car trip duration calculated. $T_{O}$ shows the duration of walking time in which the distance from $\mathrm{i}$ point to car $\left(\mathrm{N}_{\mathrm{i}}\right) . \mathrm{T}_{\mathrm{a}}$ refers to trip time that is spend in the car from $\mathrm{N}_{\mathrm{i}}$ to $\mathrm{N}_{\mathrm{j}}$ point. $\mathrm{T}_{\mathrm{D}}$ shows the duration of walking time in which the distance from $\mathrm{N}_{\mathrm{j}}$ to $\mathrm{j}$ arrival point. There would be roughly no delays or cancels because of car ownership. Thus there is no random variable in the car trip [10].

Modelling area divided into the cells. The size of a cell is $100 \times 100$ meters. Main cell is HSR station and all equations are calculated based on this cell. A utility index has examined for each cell by adding accessibility index and utility function results. All cells can turn an upper function which is defined before. In this study, transition of a cell to an upper function defines as [41]: recreational and green area $>$ services (health, education etc.) $>$ commercial area $>$ residential area $>$ industrial area $>$ empty area.

So far, empty area turns into all functions. An industrial area turns into a residential, commercial, service or recreational and green area. Therefore, a residential area also turns into a commercial, service or recreational and green area but never turns into an industrial area. Recreational and green area is a public area and mainly in this study these areas are accepted never turn into another function due to public necessities. HSR station, which is the main cell for our study, effects all cells in terms of accessibility and utility. Zone distance is calculated as a $5 \mathrm{~km}$ radius where HSR station locates in the center of study area (Fig. 1 and Fig. 3) [10]. 
Basically, all transport investments aim to reduce the trip time. In Ankara-Konya route, the aim is achieved and people chose HSR mode. Meanwhile, it is clear that when a HSR service arrives in a city, it effects the economic activities and land use distribution around the station, development of new residential areas and transport demands of passengers [5]. As it happened in the case study area, industrial zones are turned commercial and mix-used zones into. Therewithal, settlement choice of passengers is also directly affected by location of HSR station.

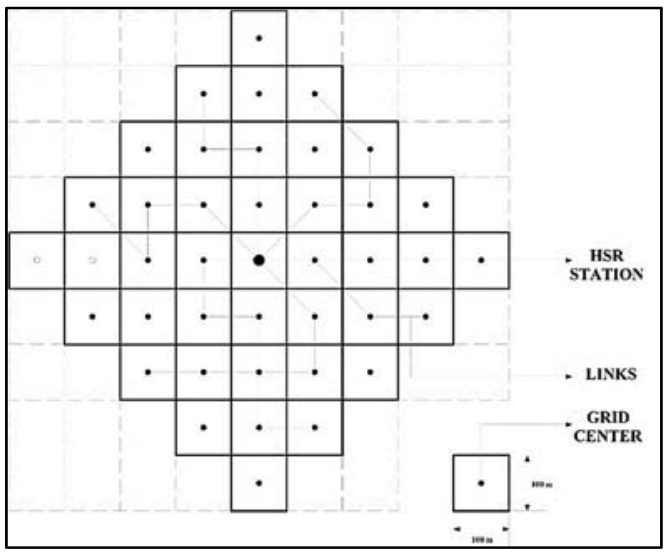

Figure 3: Scheme of cells. (Source: Scheme drawn by authors.)
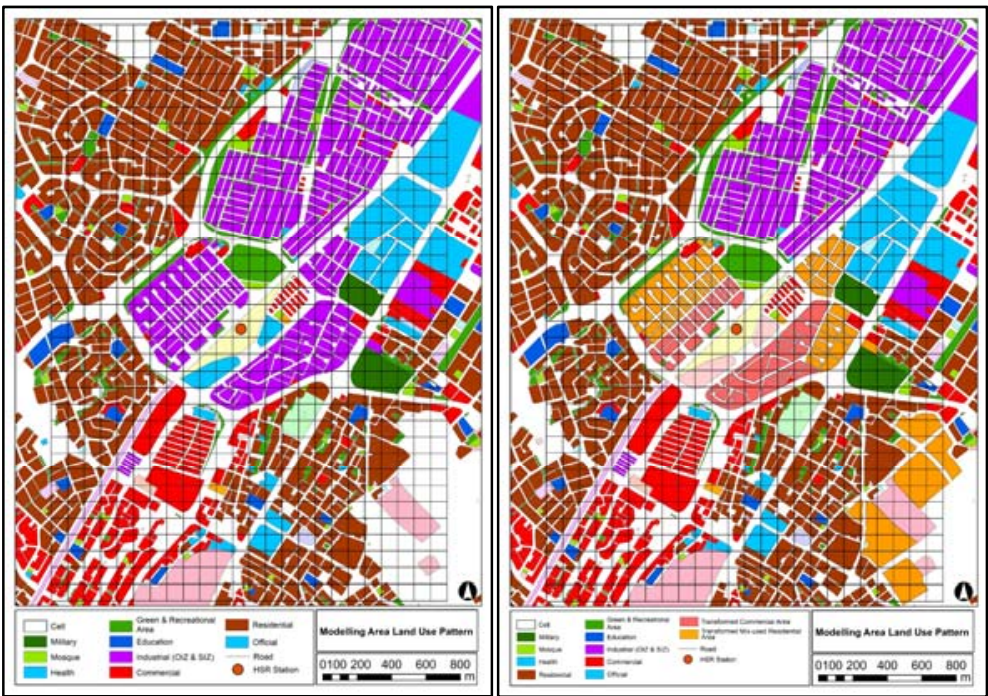

Figure 4: Comparison of scheme modelling area by land use pattern before and after the construction of HSR station. (Source: Scheme drawn by authors.) 


\section{CONCLUSION}

There is not much literature about the impact of HSR systems in Turkey due to the fact that high speed train is a new transportation mode. For this reason, our study underlines the need for evaluating the effects of HSR systems from the point of accessibility and spatial impacts. It is clear that the study needs to be examined much detail various data. Especially, spatial analysis is very important to show the differences of land use pattern and functional distribution before and after HSR systems. Thus, the study contributes the literature on HSRs from the point of Turkey HSR investments.

The relationship between HSR station and transportation mode has positive manner. It is easy to say that people choose HSR systems if the ticket price is affordable and the time saving is acceptable. The study shows that how a transportation mode can change the passenger demands and spatial distribution by a public investment. To achieve these aims, whole transportation systems have to be integrated and new settlements and big activity functions must be located according as HSR stations.

Spatial equity is less examined issue in the study. As Kim and Sultana (2015) mentioned HSR systems could be an important element to enhance the spatial equity between the regions [12]. On the other hand, by HSR systems reducing the regional divergence, some other small cities, which are not located in the HSR corridor, can suffer from the polarization of economic and spatial circumstance [17]. At this point, there must be some inner connections to these cities in order to eliminate the negative impact of HSR systems. Besides HSR service can be re-developed around the station by re-producing the land with a suitable function as residential, industrial, commercial, educational, recreational and so on.

There are also much topics needed to be solved in Turkey. One of them is integration of HSR systems to the Europa lines. Endogenously Turkish HSR systems could run in some routes such as Ankara-Konya or Ankara-İstanbul. However, compare the whole HSR projects, it is difficult to claim that it would be as successful as the formers. There isn't enough evidence to prove this claim. Even three of Turkish HSR lines run efficiently, future investments are planned carefully in order to avoid unnecessary constructions because of expensive construction costs. Besides, without Europe and Asia connections, Turkish HSR lines don't make sensible adequate contribution to enhance the spatial equity. At this point, perhaps we need to ask a question; is it possible to connect all HSR lines in the world and what could be the impacts of this situation?

\section{ACKNOWLEDGEMENT}

This study was funded during the survey by İTÜ BAP Offices. We here thank the office for their funding.

\section{REFERENCES}

[1] Vickerman, R., High-speed rail in Europe: Experience and issues for future development. The Annals of Regional Science, 31, pp. 21-38, 1997.

[2] Rus, G.D. \& Inglada, V., Cost-benefit analysis of the high-speed train in Spain. The Annals of Regional Science, 31, pp. 175-188, 1997.

[3] Casares, P. \& Millan, P.C., Passenger transport planning. A benefit-cost analysis of the high speed railway: The case of Spain. Atlantic Review of Economics, 2, pp. 1-12, 2011.

[4] Fröidh, O., Market effects of regional high speed trains on svealand line. Journal of Transport Geography, 13, pp. 352-361, 2005.

[5] Monzon, A., Ortega, E. \& López, E., Efficiency and spatial equity impacts of high speed rail extensions in urban areas. Cities, 30, pp. 18-30, 2013. 
[6] Doomernik, J.E., Performance and Efficiency of High-speed Rail Systems, Transportation Research Procedia, 8, pp. 136-144, 2015.

[7] Chen, Z., Xue, J., Rose, A.Z. \& Haynes, K.E., The impact of high-speed rail investment on economic and environmental change in China: A dynamic CGE analysis, Transportation Research Part A, 92, pp. 232-245, 2016.

[8] Givoni, M., Development and Impact of the Modern High-Speed Train: A Review, Transport Review, 26(5), pp. 593-611, 2006.

[9] Urena, J.M., Menerault, P. \& Garmendia, M., The high speed rail challenge for big intermediate cities: A national regional and local perspective. Cities, pp. 266-279, 2009.

[10] Shen, Y., Silva, J.D. \& Martinez, L.M., Assessing high speed rail's impact on land cover change in large urban areas based on spatial mixed logit methods: A case study of Madrid Atocha railway station from 1990 to 2006. Journal of Transport Geography, pp. 184-196, 2014.

[11] Yin, M., Bertolini, L. \& Duan, J., The effects of the high-speed railway on urban development: International experience and potential implications for China. Progress in Planning, pp. 1-52, 2015.

[12] Kim, H. \& Sultana, S., The Impacts of high speed rail extension on accessibility and spatial equity changes in South Korea from 2004 to 2018. Journal of Transport Geography, pp. 48-61, 2015.

[13] Vickerman, R., High speed rail and regional development: The case of intermediate station. Journal of Transport Geography, 42, pp. 157-165, 2015.

[14] Zhang, W., Nian, P. \& Lyu, G., A multimodal approach to assessing accessibility of high-speed railway station. Journal of Transport Geography, 54, pp. 91-101, 2016.

[15] Albalate, D. \& Fageda, X., High speed rail and tourism: Empirical evidence from Spain. Transportation Research Part A, 85, pp. 174-185, 2016.

[16] López, E., Gutiérrez, J. \& Gómez, G., Measuring regional cohesion effects of large scale transport infrastructure investments: an accessibility approach. European Planning Studies, 16(2), pp. 277-301, 2008.

[17] Hall, P., Magic carpets and seamless webs: Opportunities and constraints for highspeed trains in Europe. Built Environment, 35(1), pp. 59-69, 2009.

[18] T.C.D.D, 2011-2015 T.C. Devlet Demiryolları İstatistik Yıllığı, T.C.D.D Araştırma Planlama ve Koordinasyon Daire Başkanlığı, Ankara, 2016.

[19] UIC, High Speed Lines in the World, 2017.

[20] TOBB, Hızlı Tren Projesini Değerlendirme Paneli, Ankara: TOBB Yayınları, 1993.

[21] European Commission, Council Directive 96/48/EC - Interoperability of the Trans-European High Speed Rail System, 1996.

[22] Chen, C.L., The spatial-economic impact of high-speed trains: nationally (The UK IC 125) and regionally (A British-French comparison), Londra: PhD thesis, 2013.

[23] Bouley, J., Innovative areas: High speeds, in: ECMT, European conference of minister of transport, 1 içinde European Dimension and Future Prospects of the Railways, Paris, 1986.

[24] Shaw, S.L., Impacts of high speed rail on railroad network accessibility in China. Journal of Transport Geography, 40, pp. 112-122, 2014.

[25] Sanfeliu, C.B. \& Palomero, A.G., Cities and railways in Spain in the 21st century: integrating the high-speed train in the urban environment. Boletin de la Asociación de Geógrafos Españoles, 55, pp. 433-438, 2011.

[26] Takagi, R., High speed railways the last 10 years. Japan Railway and Transport Review, 40, pp. 4-7, 2005. 
[27] Aeromobil, Flying Car, Aeromobil, Available on: https:// www.aeromobil.com/ flying-car/.

[28] TÜIKK, Seçilmiş Göstergelerle Konya 2013, Ankara: Türkiye Istatistik Kurumu Matbaas1, 2014.

[29] SGK, SGK Istatistik Yıllığ1 2010-2015, Available on: http:/www.sgk.gov.tr/ $\mathrm{wps} / \mathrm{portal} / \mathrm{sgk} / \mathrm{tr} / \mathrm{kurumsal} /$ istatistik/sgk istatistik yilliklari.

[30] YÖK, Yüksek Öğretim Kurumu, Availab̄le on: https://istatistik.yok.gov.tr/.

[31] İl Kültür ve Turizm Müdürlüğü, Konya İl Kültür ve Turizm Müdürlüğü, Available on: http://www.konyakultur.gov.tr/index.php?route=pages/pages\&page id=24.

[32] Gutiérrez, J., Location, economic potential and daily accessibility: An analysis of the accessibility impact of the high-speed line Madrid-Barcelona-French border. Journal of Transport Geography, 9, pp. 229-242, 2001.

[33] Handy, S.L. \& Niemeier, D.A., Measuring Accessibility: An Exploration of Issues and Alternatives. Environment and Planning A, 29, pp. 1175-1194, 1997.

[34] Chandra, S. \& Vadali, S., Evaluating accessibility impacts of the proposed America 2050 high speed rail corridor for the Appalachian region. Journal of Transport Geography, 37, pp. 28-46, 2014.

[35] Karayolları Genel Müdürlüğü, Mesafeler, Available on: http://www.kgm.gov.tr/ Sayfalar/KGM/SiteTr/Root/Uzakliklar.aspx.

[36] Konya Platformu, Eğitim, Kültür, Sağlık ve çevre derneği, Yüksek hızlı trenin bölgesel kalkınmaya etkileri, Konya, 2012.

[37] Wolfram, S., Random sequence generation of cellular automata. Advance in Applied Mathematics, 7, pp. 123-169, 1986.

[38] Wolfram, S., Cellular Automata and Complexity: Collected Papers, Addison-Wesley Pub. Co.: Reading, Mass, 1994.

[39] Batty, M., Cities and Complexity: Understanding Cities with Cellular Automata, Agent-Based Models, and Fractals, The MIT Press: Cambridge, Massachusetts, 2005.

[40] Doğan M., Ankara-Konya yüksek hızlı tren projesi kapsamında konya ili yolculuk zaman değeri, Akademik Bakış Dergisi, 33, 2012.

[41] Yüzer, M.A., Şehirsel Yerleşmelerde Fraktal ve Hücresel Otomata Yöntemi ile Gelişme Alanlarının Belirlenmesi, İstanbul: PhD thesis, İTÜ, 2001. 